\title{
Ultrastructure of intracytoplasmic Rickettsia-like infection of the gills of the teleost Archosargus probatocephalus (Sparidae) in northeastern Brazil
}

\author{
Ultraestrutura de Rickettsia intracitoplasmática infectando as brânquias do \\ teleósteo Archosargus probatocephalus (Sparidae) no Nordeste do Brasil
}

\author{
Themis Jesus Silva1* (D); Graça Casal2,3 (D); Emerson Carlos Soares ${ }^{1}$ (D); Sónia Rocha ${ }^{2,4}$ (D); Elton Lima Santos ${ }^{1}$ (D); \\ Elsa Oliveira ${ }^{4}$ (D); Carlos Azevedo ${ }^{2,4}$ (D)

\footnotetext{
'Laboratório de Aquicultura, Centro de Ciências Agrárias - CECA, Universidade Federal de Alagoas - UFAL, Rio Largo, AL, Brasil Porto - UP, Portugal CESPU, Gandra, Portugal

${ }^{4}$ Laboratório de Biologia Celular, Instituto de Ciências Biomédicas - ICBAS, Universidade do Porto - UP, Porto, Portugal
} \\ ${ }^{2}$ Laboratório de Patologia Animal, Centro Interdisciplinar de Investigação Marinha e Ambiental - CIIMAR, Universidade do Porto, \\ ${ }^{3}$ Instituto Universitário de Ciências da Saúde, Instituto de Investigação e Formação Avançada em Ciências e Tecnologias da Saúde -
}

How to cite: Silva TJ, Casal G, Soares EC, Rocha S, Santos EL, Oliveira E, et al. Ultrastructure of intracytoplasmic Rickettsia-like infection of the gills of the teleost Archosargus probatocephalus (Sparidae) in northeastern Brazil. Braz J Vet Parasitol 2020; 29(3): e010020. https://doi.org/10.1590/S1984-29612020067

\begin{abstract}
A histopathological survey was conducted to investigate the presence of microparasites in fish Archosargus probatocephalus, in a river near Maceió, Brazil. Light microscope observations of fragments of gill showed the presence of small cysts containing numerous myxospores that were morphologically identified as Henneguya. Transmission electron microscopy observations further revealed several gill cells containing groups of prokaryotic cells within large cytoplasmic vacuoles. Each infected host cell displayed a single vacuole containing a variable number of Rickettsia-like cells (up to 11), some of which presented the dumbbell shape characteristic of binary fission. The Rickettsia-like cells were pleomorphic, without a nucleus and with chromatin dispersed in the cytoplasm. They had a thin electron-dense wall of Gram-negative type. The morphology of these prokaryotic was similar to those of the order Rickettsiales and was described as a Rickettsia-like organism. Histopathological evaluation showed that several vacuole membranes had a lysed appearance. Some had ruptured, thus allowing direct contact between the Rickettsia-like organism and the cytoplasm of the host cell. The rupturing of the branchial epithelium may have contributed towards reduction of the surface area of the gills, but it is not possible to say that this was the cause of the host's death.
\end{abstract}

Keywords: Fish, Sparidae, cytoplasmic vacuoles, Rickettsia-like cell.

\begin{abstract}
Resumo
Um levantamento histopatológico foi realizado para pesquisar a presença de microparasitas, no peixe Archosargus probatocephalus em um rio próximo a Maceió, Brasil. Observações ao microscópio óptico de fragmentos de brânquias mostraram a presença de pequenos cistos contendo numerosos mixósporos, identificados morfologicamente como Henneguya. Ocasionalmente, na microscopia eletrônica de transmissão, foram observados vários corpos citoplasmáticos de inclusão, grupo aparentemente de células procarióticas que vivem dentro de um grande vacúolo citoplasmático de algumas células branquiais. As células hospedeiras infectadas tinham um único vacúolo contendo um número variável de células do tipo Rickettsia, até 11, algumas das quais em forma do haltere, característica da fissão binária. Essas células eram pleomórficas sem núcleo, tendo a cromatina dispersa no citoplasma e possuíam uma parede densa de elétrons finos do tipo Gram-negativo. A morfologia dessas células procarióticas foi semelhante àquelas da ordem Rickettsiales e foram descritas como organismos tipo Rickettsiae. A histopatologia mostra várias membranas de vacúolos circundantes com aspetos lisados, enquanto outras apresentam rupturas que mostram contato direto do organismos tipo Rickettsiae com o citoplasma da célula
\end{abstract}

Received April 28, 2020. Accepted July 1, 2020

*Corresponding author: Themis Jesus Silva. E-mail: themisjdasilva@gmail.com

This is an Open Access article distributed under the terms of the Creative Commons Attribution License, which permits unrestricted use distribution, and reproduction in any medium, provided the original work is properly cited. 
hospedeira. A ruptura do epitélio branquial pode ter contribuído para a redução da superfície das brânquias, mas não é possível afirmar que foi a causa da morte do hospedeiro.

Palavras-chave: Peixe, Sparidae, vacúolo citoplasmático, célula tipo Rickettsia.

\section{Introduction}

Occurrences of cell-dependent prokaryotic microorganisms such as Bacteria, Rickettsiae, Mycoplasma and Chlamydia in eukaryotes has been described worldwide. These are commonly associated with differing pathogenicity in many geographical regions (Athanassopoulou \& Karagouni, 2004; Azevedo, 1993; Azevedo et al., 2005; Birkbecka \& Ringøb, 2005; Bower et al., 1994; Cusack et al., 2002; Fryer et al., 1990; Fryer \& Lannan, 1994; Guo et al., 2004; Molloy et al., 2001; Turnbull, 1993; Villalba et al., 1999; Yuksel et al., 2006). Rickettsial and bacterial diseases that affect a wide range of freshwater, brackish water and marine fish (Bower et al., 1994; Mauel et al., 2003; Soares et al., 2013; Weinert et al., 2009), including ornamental species (Mauel et al., 2007) have been described. Elevated economic losses due to occurrences of rickettsial infections in cultivated fish have also frequently been reported (Branson \& Diaz-Munoz, 1991; Chern \& Chao, 1994; Corbeil et al., 2005; Cusack et al., 2002; Fryer et al., 1990; Mauel et al., 2003).

Subsequently, several experiments have been conducted to evaluate the effects of different chemical biocide products on the development of rickettsial species (Mauel et al., 2003; Miquel et al., 2003; Palmer et al., 1996; Smith et al., 1996).

Over recent years, rickettsial diseases have been observed in various locations and in a variety of species, infecting different organs, how: the clam gills from Island Lizard (Great Barrier Reef) (Goggin \& Lester, 1990); the renal tissue of Chilean salmon (Oncorhynchus kisulch) (Fryer et al., 1992); the gills of the oyster (Crassostrea gigas) collected in Spain and the digestive gland of the shrimp (Pandalus platyceros) from Canada (Bower et al., 1994) and the kidney, liver and spleen of juvenile Atractoscion nobilis, from the USA (Chen et al., 2000). The rickettsiosis were found to be especially important in salmon farms, where high mortality was observed (Branson \& Diaz-Munoz, 1991; Chern \& Chao, 1994; Corbeil et al., 2005; Cusack et al., 2002; Fryer et al., 1990; Guo et al., 2004).

These prokaryotic microorganisms cause chronic systemic infections associated with internal and external lesions. Rickettsia-infected fish show lethargic and anorexic behavior, an enlarged abdominal cavity and lesions in various tissues and organs such as the liver, swim bladder and epithelial and muscle tissues, among others. They may also cause epithelial hyperplasia, which results in fusion of the gill lamellae (Branson \& Diaz-Munoz, 1991; Chern \& Chao, 1994).

Human infections caused by ingestion or handling of Rickettsia-infected fish have frequently been reported (Lu et al., 2019; Novotny et al., 2004; Shotts, 1987).

Prokaryotic parasites have most frequently been described infecting the cytoplasm (Azevedo, 1993; Cusack et al., 2002; Guo et al., 2004) and nuclei of eukaryotic hosts (Azevedo, 1989), or living in association with other prokaryotic cells (Azevedo \& Villalba, 1991). They may be pathogenic and lethal (Austin \& Austin, 2007; Chen et al., 2000; Mauel et al., 2003; Toranzo et al., 2005), and are considered to be obligate parasite (Austin \& Austin, 2007).

The fish species Archosargus probatocephalus (Walbaum, 1792), commonly known as the "sargo" or sheepshead seabream, belongs to the family Sparidae of the order Perciformes, and has wide distribution, ranging from Nova Scotia (Canada) to Brazil (Adams et al., 2018). It is considered to be a species with high potential for aquaculture because of its tolerance to wide temperature ranges, its euryhaline and omnivorous nature and the excellent quality of its meat (Rojas-Castañeda et al., 2017).

Several studies have suggested that rickettsial species and Rickettsia-like organisms (RLOs) are pathogenic and capable of causing the death of their hosts (Almendras \& Fuentealba, 1997; Yuksel et al., 2006; Rozas \& Enríquez, 2014).

The aim of this paper was to describe the ultrastructure of intracytoplasmic prokaryotic cells that cause damage to the organization of the gill cells of Archosargus probatocephalus. These cells were morphologically identified as belonging to the group of RLOs and were found in a survey on microparasites of the gill tissues of a commercially important teleost in Brazil. This formed the first description of these cells in Brazil. 


\section{Methodology}

Four adult specimens of the sheepshead seabream Archosargus probatocephalus (Brazilian common name "sargo or sargo-de-dente"), were not breeding, with lengths between 15 and $25 \mathrm{~cm}$, were collected from the estuary of the Ipioquinha River $\left(9^{\circ} 29^{\prime} \mathrm{S} / 35^{\circ} 34^{\prime} \mathrm{W}\right)$, a river partially preserved near the city of Maceió (Alagoas), Brazil, in June and August 2019. They were transported to the aquaculture laboratory of the Agrarian Sciences Center of the Federal University of Alagoas, where biometrics and dissection were performed. Collections were carried out under license number 56475-1, of November 15, 2016, renewed on December 8, 2019 MMA of Brazil.

\section{Light microscopy (LM) and transmission electron microscopy (TEM)}

Small fragments of tissues from different organs were checked under a light microscope, to detect any microparasites that might have been present. Small cysts were observed in the gills of a single specimen. The infected material was photographed under this microscope and was then processed for ultrastructural observations.

For TEM, infected fragments of gill tissue were fixed in 4-5\% glutaraldehyde in $0.2 \mathrm{M}$ sodium cacodylate buffer $(\mathrm{pH} 7.2-7.4)$ for $10-12 \mathrm{~h}$. They were then washed overnight in the same buffer and postfixed with $2 \%$ osmium tetroxide in the same buffer for $3 \mathrm{~h}$. All these steps were done at $4{ }^{\circ} \mathrm{C}$. This was followed by dehydration through an ascending ethanol and propylene oxide series and embedding in Epon to form blocks. Semithin sections $(\sim 1 \mu \mathrm{m}$ thick) were stained with methylene blue-Azur II. Ultrathin sections were double-contrasted with uranyl acetate and lead citrate, and were observed using a TEM (JEOL 100CXIl; JEOL Optical, Tokyo, Japan), operated at 60 kV.

\section{Results}

A single specimen displayed infection by myxosporean species contained within cysts, which measured up to $125 \mu \mathrm{m}$ and appeared located in the peripheral region of the gill filaments (Figure 1A). The cysts were surrounded by several layers of epithelial cells, some of which displayed cytoplasmic vacuoles containing small dense bodies that could not be identified in semithin sections (Figure 1A). TEM observations revealed that the ultrastructural aspects of these small bodies were congruent with the morphological features of prokaryotic organisms, namely RLOs (Figure 1B-F).

The RLOs were found in variable numbers per section (most frequently 5-7) (Figure 1B, F). Serial ultrathin sections showed variable numbers of RLOs (up to 11) located within several voluminous vacuoles of the infected host cells (Figure 1C-E). These vacuoles were more frequently located at the periphery of the epithelial cells in which the cysts were located (Figure 1B, C). Most of them displayed a degraded membrane and presented various aspects of rupture and RLO release (Figure 1C - F). The cytoplasm of the host cell surrounding the vacuole membrane also showed an appearance of severe lysis (Figure 1C-E).

The RLOs were pleomorphic, and their DNA appeared randomly distributed in the internal granular cytoplasm, forming a reticular nucleoid without a nuclear envelope (Figure 1D-F). The nuclear envelope and the nucleoplasm of the host cells displayed typical organization (Figure 1 C-E).

In these observations, it was not possible to detect morphological aspects that would suggest that the RLOs had influenced mortality.

\section{Discussion}

Intracellular prokaryotes have frequently been described in different aquatic species and in several geographical locations, as: Ruditapes decussatus (Mollusca, Bivalvia), collected in Portugal (Azevedo, 1989); Venerupis rhomboides, from Spain (Villalba et al., 1999); juvenile Atractoscion nobilis, collected in the California (USA) (Chen et al., 2000); Mytella guyanensis from, Bahia (Brazil) (Ceuta \& Boehs, 2012); Crassostrea gasar, cultivated in northeastern Brazil (Silva et al., 2015) and Oncorhynchus tshawytscha, from farms in New Zealand (Brosnahan et al., 2019).

The ultrastructural characteristics of the prokaryotic cells observed in this study, namely their pleomorphic shape and lack of mitochondria and nuclear envelope, suggested that they belonged to the order Rickettsiales, genus Rickettsia. They are described here as Rickettsia-like organisms (RLOs). The morphological characteristics that identify these RLOs have already been described in numerous reports (Azevedo \& Villalba, 1991; Cusack et al., 2002; Guo et al., 2004). The ultrastructure of the outer membrane of the cell wall and cytoplasmic membrane further 

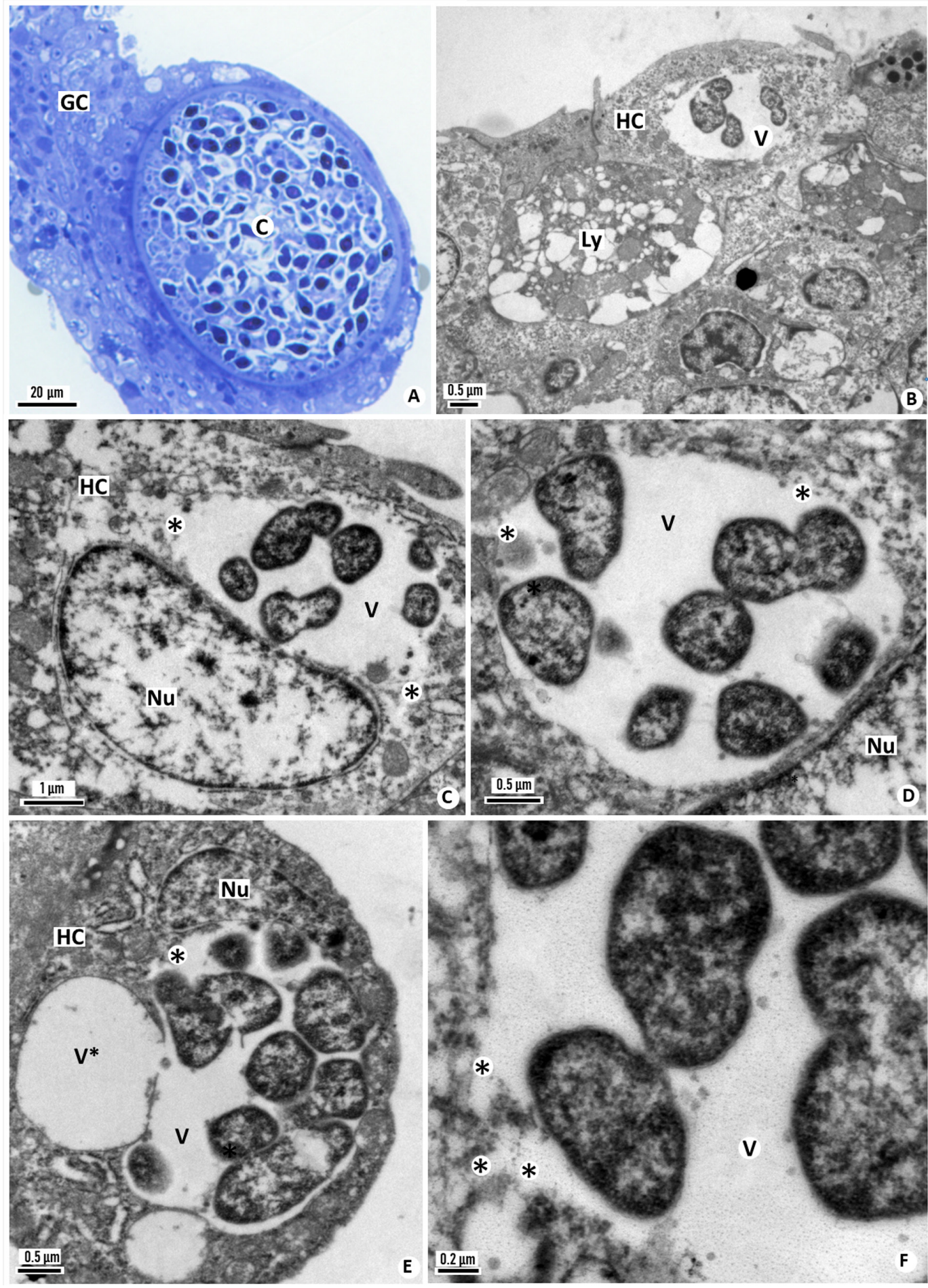

Figure 1 Light and transmission electron microscopy aspects of gill epithelial cells of the teleost Archosargus probatocephalus. Some of these cells presented generally a single large cytoplasmic vacuole containing Rickettsia-like organisms (RLOs). A - Semithin section of a cyst (C) containing myxospores surrounded by different gill cells (GC), infected by RLOs within vacuoles that were hardly observed in LM; B - Ultrathin section showing the periphery of the gill, where an infected host cell (HC) with a vacuole (V) containing some Rickettsia-like cells are present. Near the vacuole (V), some cellular material seems lysed (Ly); C - Ultrastructural appearance of an infected host cell (HC) located near to the periphery of the gill, in which the nucleus (Nu) is in contact with the vacuole (V) containing the RLOs. The HC shows high-grade of lysis (*); D - Ultrastructural appearance of the cytoplasm of a host cell containing a vacuole (V) with several pleomorphic RLOs. The cytoplasm of the host cell and the membrane of the vacuole show advanced stages of degradation $\left(^{*}\right)$. Partial portion of the nucleus $(\mathrm{Nu})$ showing the closed contact with the vacuole content; $\mathrm{E}$ - Ultrastructural details of a host cell $(\mathrm{HC})$ showing two type of vacuoles. The biggest containing several RLOs $(V)$, while the smallest one $\left(V^{*}\right)$ appeared empty of RLOs. The vacuole membrane and the nucleus $\left({ }^{*}\right)$ show degraded aspects. F - Ultrastructural details showing some RLOs within the vacuole (V) that seems well preserved, while the membrane and the surrounding cytoplasm of the host cell appears highly lysed $\left({ }^{*}\right)$. 
revealed them to be Gram-negative. This information was not given in most previous descriptions (Fryer \& Lannan, 1994), with the exception of Fryer \& Hedrick (2003).

This was the first description of an intracellular prokaryotic RLO from this Brazilian host fish (Archosargus probatocephalus). This seems to be a situation that has frequently been encountered, with occasional reports of numerous eukaryotic cells in aquatic species in different taxonomic groups. It also seems to occur more frequently as an intracytoplasmic infection (Azevedo, 1993; Azevedo et al., 2005), than as an intranuclear infection (Azevedo, 1989). In another report, a giant rickettsial organism associated with bacteria in the molluscan gills of Crassostrea gigas caused host mortality (Azevedo \& Villalba, 1991).

Intracellular prokaryotic microorganisms have never before been reported from the sheepshead seabream. This fish species is distributed along large proportions of the North and South American Atlantic coasts (Rojas-Castañeda et al., 2017). Thus, the present study constitutes the first description of an intracytoplasmic prokaryote in this fish species, and specifically from a geographical region where it is commercially valuable for human consumption.

The lack of data in the literature with regard to vacuole-forming intracytoplasmic infections in fish hosts hampers recognition of the degree of tissue degradation that may result from these types of infections, along with detailed assessment of the histopathological effects of RLOs. Considering that the present study resulted from a chance finding during the course of a myxozoan survey conducted on Archosargus probatocephalus (work in progress), we are unable to say whether the RLOs described here can increase host mortality. Nevertheless, a previous study showed that infection by RLOs may occur through weakened host immunity, as a result of abiotic changes to the aquatic environment (Soares et al., 2013).

It is well known that various species of invertebrates, and especially arthropods and bivalves, act as transmission vectors for RLOs. However, no information is available regarding the possibility that infected fish might be active transmitters of rickettsiosis.

Our results do not allow any suggestions regarding the mode of infection or development of these prokaryotic parasites within the host. The way in which the RLOs were organized, with evidence of vacuole membrane rupture and degradation of host cytoplasm, suggests that they possibly had pathogenic activity.

Little is known about the mechanisms through which RLOs penetrate into host cells (Austin \& Austin, 2007). Some studies have suggested that food vacuoles (phagosomes) may be a possible means through which RLOs enter into host cells (Silverman et al., 1992). Others have described action mediated by phospholipase, i.e. "induced phagocytosis" (Silverman et al., 1992). Occurrences of dissemination to neighboring cells, were reported by Weddle \& Agaisse (2018), who observed that RLOs used the cytoskeleton of the host cell to move from infected cells and project to adjacent cells.

Experimental results from artificial infestation of fish with Rickettsia have suggested that cell penetration occurs through the skin and gills (Smith et al., 1999, 2004). Some authors have suggested that occurrences of rickettsiosis may result from biotic factors such as pathogens and abiotic causes such as pollution (Austin \& Austin, 2007). Considering that, in the present study, RLOs were found contained within cytoplasmic vacuoles located on the periphery of gill epithelial cells, our observations support the idea that RLO penetration occurs mainly through this organ. In addition, the high number of RLOs contained in the same vacuole possibly suggests that penetration of host cells is accompanied by occurrences of cell division, from a single penetrating RLO.

Further detailed observations are needed in order to better understand the evolution of RLOs, which will help in the future to elucidate the mechanisms of host infection, life cycle, transmission and pathogenicity.

\section{References}

Adams GD, Leaf RT, Ballenger JC, Arnott SA, McDonough CJ. Spatial variability in the growth of Sheepshead (Archosargus probatocephalus) in the southeast US: implications for assessment and management. Fish Res 2018; 206: 35-43. http://dx.doi. org/10.1016/j.fishres.2018.04.023.

Almendras FE, Fuentealba IC. Salmonid rickettsial septicemia caused by Piscirickettsia salmonis: a review. Dis Aquat Organ 1997; 29(2): 137-144. http://dx.doi.org/10.3354/dao029137.

Athanassopoulou F, Karagouni E. Rickettsia-like organisms (R.L.O.) infections of fin-fish.J Hell Vet Med Soc 2004; 55(2): 165-173. http://dx.doi.org/10.12681/jhvms.15188. 
Austin B, Austin DA. Bacterial fish pathogens. diseases of farmed and wild fish. 4th ed. United Kingdom: Springer-Praxis Publishing; 2007. https://doi.org/10.1007/978-1-4020-6069-4.

Azevedo C, Padovan I, Corral L, Padovan P. Ultrastructural description of an unidentified apicomplexan oocyst containing bacteria-like hyperparasites in the gill of Crassostrea rizophorae. Dis Aquat Organ 2005; 65(2): 153-157. http://dx.doi.org/10.3354/ dao065153. PMid:16060268.

Azevedo C, Villalba A. Extracellular giant rickettsiae associated with bacteria in the gill of Crassostrea gigas (Mollusca, Bivalvia). $J$ Invertebr Pathol 1991; 58(1): 75-81. http://dx.doi.org/10.1016/0022-2011(91)90164-L. PMid:1885924.

Azevedo C. Fine structure of endonucleobiotic bacteria in gill epithelium of Ruditapes decussatus. Mar Biol 1989; 100(3): 339-341. http://dx.doi.org/10.1007/BF00391149.

Azevedo C. Occurrence of an unusual branchial mycoplasma-like infection in cockle Cerastoderma edule (Mollusca, Bivalvia). Dis Aquat Organ 1993; 16: 55-59. http://dx.doi.org/10.3354/dao016055.

Birkbecka TH, Ringøb E. Pathogenesis and the gastrointestinal tract of growing fish. Biol Grow Anim 2005; 2: 208-234. http:// dx.doi.org/10.1016/S1877-1823(09)70043-8.

Bower SM, McGladdery SE, Price IM. Synopsis of infection diseases and parasites of commercially exploited shellfish. Annu Rev Fish Dis 1994; 4: 1-199. http://dx.doi.org/10.1016/0959-8030(94)90028-0.

Branson EJ, Diaz-Munoz DN. Description of a new disease condition occurring in farmed coho salmon, Oncorhynchus ksiutch (Walbaum), in South America. J Fish Dis 1991; 14(2): 147-156. http://dx.doi.org/10.1111/j.1365-2761.1991.tb00585.x.

Brosnahan CL, Munday JS, Ha HJ, Preece M, Jones JB. New Zealand rickettsia-like organism (NZ-RLO) and Tenacibaculum maritimum: distribution and phylogeny in farmed Chinook salmon (Oncorhynchus tshawytscha). J Fish Dis 2019; 42(1): 85-95. http://dx.doi. org/10.1111/jfd.12909. PMid:30411368

Ceuta LO, Boehs G. Parasites in the mangrove mussel Mytella guyanensis (Bivalvia: Mytilidae) in Camamu Bay, Bahia, Brazil. Braz J Biol 2012; 72(3): 421-427. http://dx.doi.org/10.1590/S1519-69842012000300002. PMid:22990810.

Chen MF, Yun S, Marty GD, McDowell TS, House ML, Appersen JA, et al. A Piscirickettsia salmonis-like bacterium associated with mortality of white seabass Atractoscion nobilis. Dis Aquat Organ 2000; 43(2): 117-126. http://dx.doi.org/10.3354/dao043117. PMid:11145452.

Chern RS, Chao CB. Outbreaks of a disease caused by rickettsia-like organism in cultured tilapias in Taiwan. Fish Pathol 1994; 29(2): 61-71. http://dx.doi.org/10.3147/jsfp.29.61.

Corbeil S, Hyatt AD, Crane MSJ. Characterisation of an emerging rickettsia-like organism in Tasmania farmed Atlantic salmon Salmo salar. Dis Aquat Organ 2005; 64(1): 37-44. http://dx.doi.org/10.3354/dao064037. PMid:15900686.

Cusack RR, Groman DB, Jones SRM. Rickettsial infection in farmed Atlantic salmon in eastern Canada. Can Vet J 2002; 43(6): 435-440. PMid:12058568.

Fryer JL, Hedrick RP. Piscirickettsia salmonis: a Gram-negative intracellular bacterial pathogen of fish. J Fish Dis 2003; 26(5): 251262. http://dx.doi.org/10.1046/j.1365-2761.2003.00460.x. PMid:12962234.

Fryer JL, Lannan CN, Garcés LH, Larenas JJ, Smith PA. Isolation of a rickettsiales-like organism from diseased coho salmon (Oncorhynchus kisutch) in Chile. Fish Pathol 1990; 25(2): 107-114. http://dx.doi.org/10.3147/jsfp.25.107.

Fryer JL, Lannan CN, Giovannoni SJ, Wood ND. Piscirickettsia salmonis gen. nov., sp. nov., the causative agent of an epizootic disease in salmonid fishes. Int J Syst Bacterio/ 1992; 42(1): 120-126. http://dx.doi.org/10.1099/00207713-42-1-120. PMid:1371057.

Fryer JL, Lannan CN. Rickettsial and chlamydial infections of freshwater and marine fishes, bivalves, and crustaceans. Zoo/ Stud 1994; 33(2): 95-107.

Goggin GL, Lester RJG. Rickettsiales-like infection in the gill in Tridacna crocea from Great Barrier Reef. J Invertebr Patho/ 1990; 56(1): 135-138. http://dx.doi.org/10.1016/0022-2011(90)90156-Z. PMid:2376662.

Guo Q, Jia W, Han X, Cai T, Gong X, Sun X. Rickettsia-like organism infection in a freshwater cultured fish Ophiocephalus argus C. in China.J Progr Nat Sci 2004; 14(5): 417-422. http://dx.doi.org/10.1080/10020070412331343711.

Lu M, Li F, Liao Y, Shen J-J, Xu J-M, Chen YZ, et al. Epidemiology and diversity of Rickettsiales Bacteria in humans and animals in Jiangsu and Jiangxi provinces, China. Sci Rep 2019; 9(1): 13176. http://dx.doi.org/10.1038/s41598-019-49059-3. PMid:31511528.

Mauel MJ, Miller DL, Frazier K, Liggett AD, Styer L, Montgomery-Brock D, et al. Characterization of Piscirickettsiosis-like disease in Hawaiian tilapia. Dis Aquat Organ 2003; 53(3): 249-255. http://dx.doi.org/10.3354/dao053249. PMid:12691196.

Mauel MJ, Soto E, Moralis J, Hawke J. A piscirickettsiosis-like syndrome in cultured Nile tilapia in Latin America with a Francisella spp. as the pathogenic agent. J Aquat Anim Health 2007; 19(1): 27-34. http://dx.doi.org/10.1577/H06-025.1. PMid:18236629. 
Miquel A, Müller I, Ferrer P, Valenzuela PDT, Burzio LO. Immunoresponse of Coho salmon immunized with a gene expression library from Piscirickettsia salmonis. Biol Res 2003; 36(3-4): 313-323. http://dx.doi.org/10.4067/S0716-97602003000300004. PMid:14631865.

Molloy DP, Giamberini L, Morado JF, Fokin SI, Laruelle F. Characterization of intracytoplasmic prokaryote infections in Dreissena sp. (Bivalvia: dreissenidae). Dis Aquat Organ 2001; 44(3): 203-216. http://dx.doi.org/10.3354/dao044203. PMid:11383568.

Novotny L, Dvorska L, Lorencova A, Beran V, Pavlik I. Fish: A potential source of bacterial pathogens for human beings. Vet Med Czech 2004; 49(9): 343-358. http://dx.doi.org/10.17221/5715-VETMED.

Palmer R, Ruttledge M, Callanan K, Drinan E. A Piscirickettsiosis-like disease in farmed Atlantic salmon in Ireland-isolation of the agent. Bull Eur Assoc Fish Pathol 1996; 17(2): 68-72.

Rojas-Castañeda S, González-Reynoso L, Platas-Rosado DE, Hernández-Arzaba JC, Lango-Reynoso F, Castañeda-Chávez MR, et al. Avances del sargo Archosargus probatocephalus (WALBAUM, 1792) en la acuicultura como respuesta al cambio climático. Rev Iberoam Boecon Cambio Clim 2017; 3(5): 674-679. http://dx.doi.org/10.5377/ribcc.v3i5.5939.

Rozas M, Enríquez R. Piscirickettsiosis and Piscirickettsia salmonis in fish: a review.J Fish Dis 2014; 37(3): 163-188. http://dx.doi. org/10.1111/jfd.12211. PMid:24279295.

Shotts EB Jr. Bacterial diseases of fish associated with human health. Vet Clin North Am Small Anim Pract $1987 ; 17(1): 241-247$. http://dx.doi.org/10.1016/S0195-5616(87)50615-5. PMid:3551308.

Silva PM, Scardua MP, Vieira CB, Alves AC, Dungan CF. Survey of pathologies in Crassostrea gasar (Adanson, 1757) oysters from cultured and wild populations in the São Francisco estuary, Sergipe, Northeast Brazil.J Shellfish Res 2015; 34(2): 289-296. http:// dx.doi.org/10.2983/035.034.0210.

Silverman DJ, Santucci LA, Meyers N, Sekeyova Z. Penetration of host cells by Rickettsia rickettsii appears to be mediated by a phospholipase of rickettsial origin. Infect Immun 1992; 60(7): 2733-2740. http://dx.doi.org/10.1128/IAl.60.7.2733-2740.1992. PMid:1612741.

Smith PA, Pizarro P, Ojeda P, Contreras J, Oyanedel S, Larenas J. Routes of entry of Piscirickettsia salmonis in rainbow trout Oncorhynchus mykiss. Dis Aquat Organ 1999; 37(3): 165-172. http://dx.doi.org/10.3354/dao037165. PMid:10546046.

Smith PA, Rojas ME, Guajardo A, Contreras J, Morales A, Larenas J. Experimental infection of coho salmon Oncorhynchus kisutch by exposure of skin, gills and intestine with Piscirickettsia salmonis. Dis Aquat Organ 2004; 61(1-2): 53-57. http://dx.doi.org/10.3354/ dao061053. PMid:15584410.

Smith PA, Vecchiola IM, Oyanedel S, Garcés LH, Larenas J, Contreras J. Antimicrobial sensitivity of four isolates of Piscirickettsia salmonis. Bull Eur Assoc Fish Pathol 1996; 16: 164-168.

Soares S, Murray AG, Crumlish M, Turnbull JF, Green DM. Factors affecting variation in mortality of marine Atlantic salmon Salmo salar in Scotland. Dis Aquat Organ 2013; 103(2): 101-109. http://dx.doi.org/10.3354/dao02562. PMid:23548360.

Toranzo AE, Magariños B, Romalde JL. A review of the main bacterial fish diseases in mariculture systems. Aquaculture 2005; 246(1-4): 37-61. http://dx.doi.org/10.1016/j.aquaculture.2005.01.002.

Turnbull JF. Rickettsias and Chlamydias. In: Inglish V, Roberts RJ, Bromage NR. Bacterial Diseases of Fish. Oxford: Willey-Blackwell; 1993. p. 235-254.

Villalba A, Carballal MJ, López C, Cabada A, Corral L, Azevedo C. Branchial rickettsia-like infection associated with clam Venerupis rhomboides mortality. Dis Aquat Organ 1999; 36(1): 53-60. http://dx.doi.org/10.3354/dao036053.

Weddle E, Agaisse H. Principles of intracellular bacterial pathogen spread from cell to cell. PLoS Pathog 2018; 14(12): e1007380. http://dx.doi.org/10.1371/journal.ppat.1007380. PMid:30543716.

Weinert LA, Werren JH, Aebi A, Stone GN, Jiggins FM. Evolution and diversity of Rickettsia bacteria. BMC Bio/ 2009; 7(1): 6. http:// dx.doi.org/10.1186/1741-7007-7-6. PMid:19187530.

Yuksel SA, Thompson KD, Adams OA. Rickettsial infections of fish. Turk J Fish Aquat Sci 2006; 6: 63-78. 